\title{
Scenarios in the strategy process: a framework of affordances and constraints
}

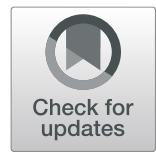

Victor Tiberius (1D

\begin{abstract}
This paper challenges the solely rational view of the scenario technique as a strategy and foresight tool designed to cope with uncertainty by considering multiple possible future states. The paper employs an affordance-based view that allows for the identification and structuring of hidden, emergent attributes of the scenario technique beyond the intended ones. The suggested framework distinguishes between affordances (1) that are intended by the organization and relate to its goals, (2) that emergently generate organizational benefits, and (3) that do not relate to organizational but individual interests. Also, constraints in the use of scenarios are discussed. Affordance theory's specific lens shows that the emergence of such attributes depends on the users' specific intentions.
\end{abstract}

Keywords: Affordances, Management, Organizations, Scenario planning, Strategic foresight

\section{Introduction}

The scenario technique has been a well-known and widely used strategy and foresight tool in organizations [23, 72]. While many other tools fail in highly uncertain environments due to their oversimplifying both problem description and possible solutions $[100,107]$, the scenario technique is a tool that has been developed for precisely such contexts [57, 81, 139]. In the following, the paper focuses on the use of the scenario technique as a specific strategy tool used in a sub-process of the overarching strategy process (Fig. 1), especially in firms. However, the conceptualization suggested in this paper can also be applied to non-profit organizations that engage in foresight activities.

Both scholars and practitioners focus on this original purpose of the scenario technique, i.e., coping with uncertainty by considering multiple possible future states. The employment of scenarios covers all functions of strategic foresight, i.e., framing, scanning, forecasting, visioning, planning, and acting [70]. The scenario technique, as a specific foresight method, enables firms to adapt to changing environments [8], to encourage innovativeness [129, $163,172]$, to create a competitive advantage [2], and to increase profitability [130].

Correspondence: tiberius@uni-potsdam.de

Faculty of Economics and Social Sciences, University of Potsdam,

August-Bebel-Strasse 89, 14482 Potsdam, Germany
However, some scholars also address further beneficial side-effects that might occur when using this tool. For example, the use of the scenario technique can foster strategic conversations [115], help in questioning existing organizational mental models, or improve organizational learning [126]. Adverse side-effects of using scenario planning are rarely discussed. For example, too much concentration on foresight activities can lead to "managerial hyperopia," the tendency of managers to focus primarily on long-term developments while neglecting pressing current issues [27]. A rather long-term orientation also leads to a more idealistic rather than pragmatic and an identityoriented rather than an instrumental perspective [87], which might also contradict a strictly rational course of action.

The existence of such side-effects demonstrates that a solely rational focus on intended outcomes is necessarily limited. A more comprehensive understanding of the scenario technique also includes its emergent attributes. These can only be considered by scholars and practitioners when they are explicitly known.

Affordance theory can provide a specific lens through which the emergent attributes can be made transparent. The scenario technique can be seen as a tool-in-use that comes with affordances, i.e., possibilities offered by the tool, as well as built-in constraints $[77,113]$.

The objective of the paper is to develop and apply a framework of the affordances and constraints of the scenario technique that allows for the identification of the 


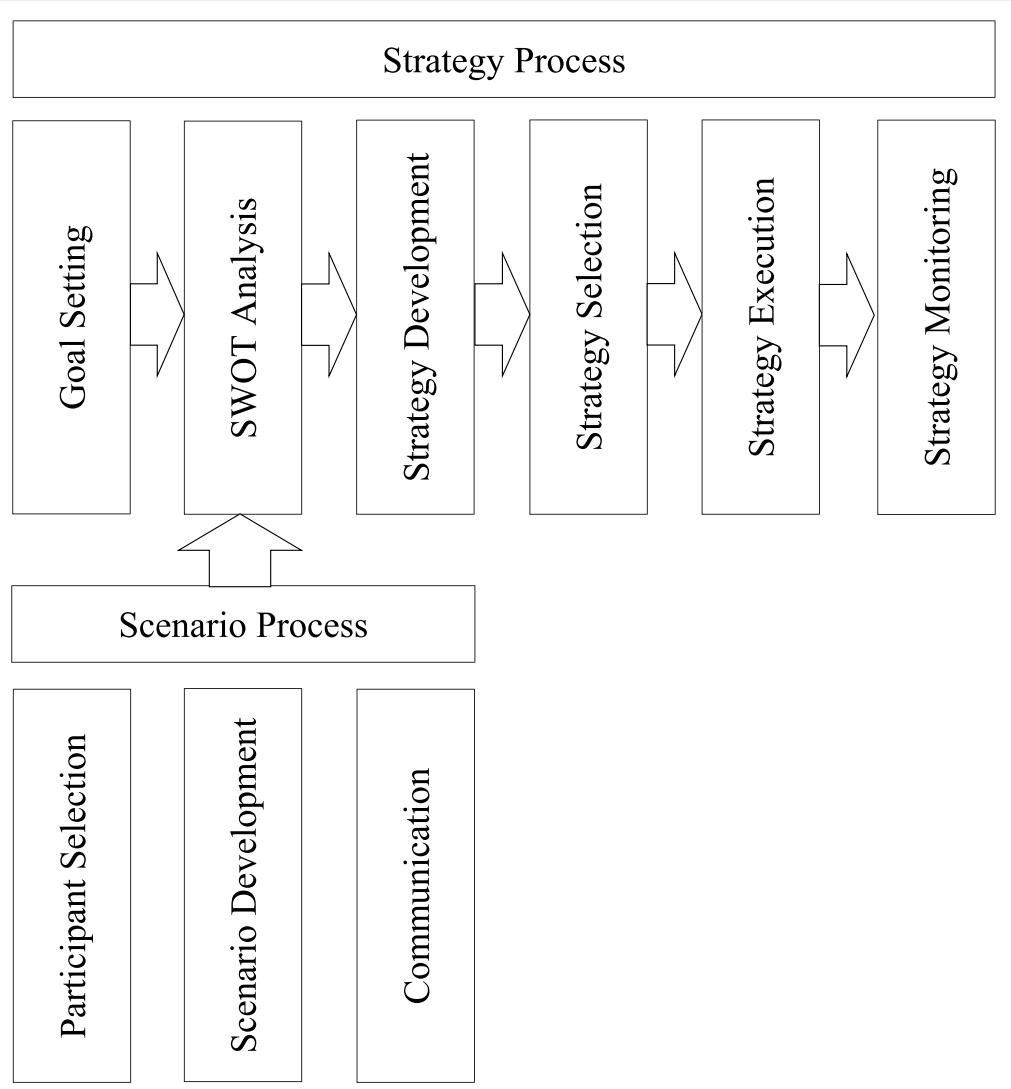

Fig. 1 The strategy and scenario processes. Source: author

full range of the multiple facets of the scenario technique and how they relate to different purposes. The suggested affordance framework is used to structure the empirical and theoretical insights from prior research on emergent attributes of the scenario technique. Additionally, related insights from the strategic foresight and the strategy literature were reviewed and applied to the scenario technique.

In particular, the paper proposes a classification that distinguishes between intended effecter affordances that aim at the pursuit of organizational goals, hidden effecter affordances that are not necessarily intended but have positive organizational side-effects, and hidden handling affordances that help scenario planners to pursue and achieve their own interests. The paper also addresses constraints that might diminish organizational performance when using the scenario technique. The paper is organized as follows: First, a short introduction into affordance theory is presented, distinguishing between three types of affordances and possible constraints relevant for organizational contexts. Second, the scenario technique as a strategy and foresight tool is analyzed regarding these affordances and constraints. Third, the implications of these findings for research and management practice are discussed.
The paper contributes to strategy and foresight research and practice in several ways. First, it introduces an affordance-based view [61] to the scenario method by referring to the strategy-as-practice school $[24,74,79,159]$ and considering the scenario technique as a specific toolin-use [77]. In this effort, the paper draws the attention to and sheds light on additional attributes beyond the originally intended use of scenarios in consideration of the actors and purposes. This reflexive and critical rather than solely rational and idealistic view can generally enhance strategy research [36] and the affordance-based view allows for a better understanding of the full spectrum of usability, nonusability, and potential misuse of the scenario technique. Due to its relational conceptualization as an attribute "between" the actor and the tool, the affordance-based view particularly reveals that not all possible attributes of scenario planning are always applicable but depend on the context, especially who participates in the process with what intentions.

\section{Affordance theory}

Affordances, first coined by ecological psychologist Gibson [58], can be seen as the properties of the environment relative to actors $[146,157]$ or, alternatively, as the relations between the features of the environment and 
abilities of actors being neither a property of the environment nor of the actor but of the relationship between them [30]. The concept has been applied in many other fields, also in the areas of the paper's scope such as organizational science $[49,92,161]$ and strategic management $[41,77]$ and it specifically relates to futureoriented action [157]. While the usual focus is on individual behavior, social affordances are also discussed, especially in organizational contexts [49].

Three types of affordances can be distinguished. First, intended effecter affordances correspond with the scenario technique's original purpose, i.e., exploring multiple futures. Second, hidden effecter affordances offer positive sideeffects that are not at the core of the scenario technique, but generate other organizational benefits. The label of being "hidden" stems from the fact that such affordances are not obvious by the design of the tool [58]. The attribute "effecter" refers to achieving desired organizational outcomes [85]. Third, hidden handling affordances enable organizational members to gain personal benefits that can be either indifferent or conflicting for the organization. In this context, the attribute "handling" addresses the affordances a tool offers to the actor, i.e., the user of the tool, as an individual as opposed to the organization this actor belongs to [85]. From a solely rational view, strategy tools are oriented toward organizational purposes only. However, actors can use strategy tools also to pursue their personal goals [77]. However, tools do not come with offered possibilities alone, but can also imply constraints. This is also the case for the scenario technique which has several fundamental restrictions inherent in its methodology.

Figure 2 shows the interrelationships between the different affordance types and constraints and their outcomes.

\section{Affordances of the scenario technique Intended effecter affordances}

The intended effecter affordances address the intended organizational purpose the scenario technique was originally designed for. Scenarios can be considered as the core concept in futures research which aims at identifying and exploring multiple possible futures that can emerge from today's point of view. A scenario can be defined as the description of a coherent image of such a possible future $[57,81]$. In the sense of the linguistic turn where researchers consider statements about reality rather than reality itself [131], futurists deal with statements about the future rather than the future itself. While futures research is completely open regarding the specific domain of inquiry, organizations are interested in feasible future developments in their specific environment that have a potential impact on them [57, 81, 139]. For example, which new technologies, products, or competitors could appear on their markets and harm their current market position? How could customer demand and behavior change? How does digitization change current business models? How could the election of a specific government leader change the legal and economic terms on a market? What would be the effect if the central bank changes its interest policy? Therefore, the scenario technique has become a popular tool in organizations $[23,72]$.

In general, two philosophies on the use of scenarios in organizations can be distinguished. In a broader sense, corporate or strategic foresight can be seen as a rather independent organizational function that delivers insights into possible future developments that can be used in several organizational contexts such as research and development, innovation management, marketing, and finance. In a narrower sense, it can be seen as an important step in the strategy process [110] which consists of organizational goal setting, the assessment of the organization's strengths and weaknesses and the environment's opportunities and threats ("SWOT"), as well as the development, selection, execution, and monitoring of strategies (Fig. 1). In this process chain, organizations have realized that it is not sufficient to assess only the current opportunities and threats in the environment, but also potential future developments, because the implementation and realization of a strategy takes time and

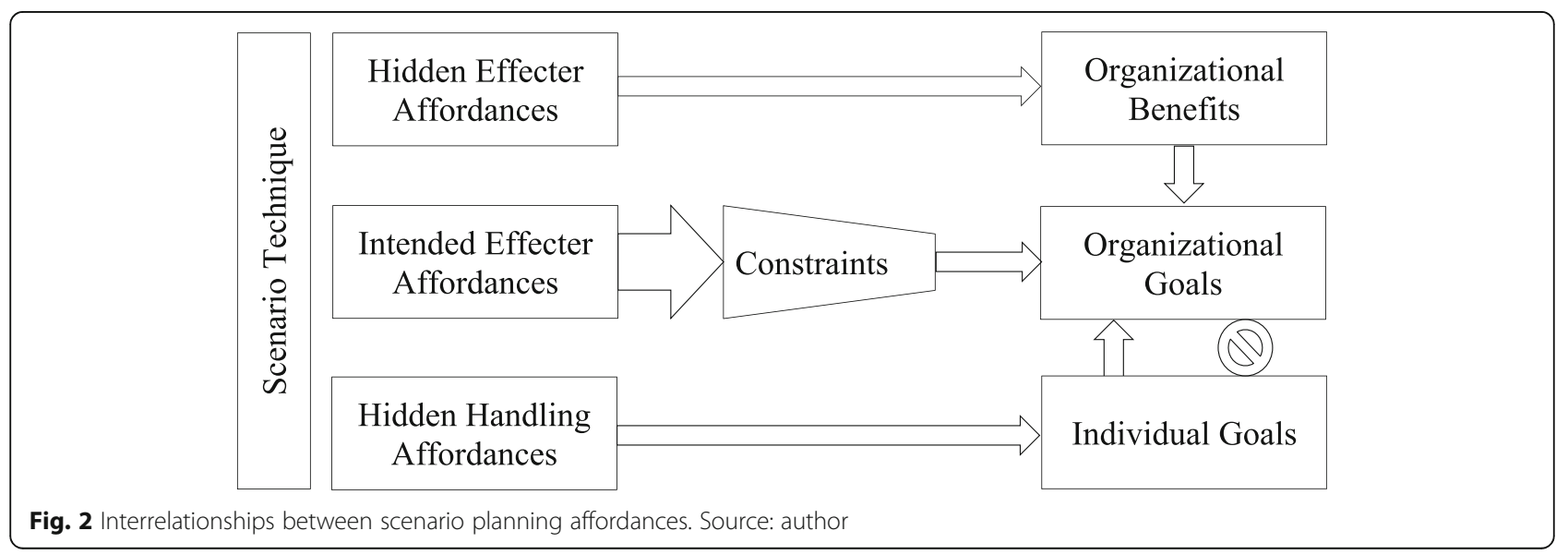


the environment is dynamic. This paper focuses on the narrower sense of the scenario technique.

Following future research's predominant paradigm of the futility of predictions and the need for the consideration of multiple feasible futures, organizations explore multiple future scenarios derived from diverse foresight methods [117] and often based on expert opinions [119]. In dealing with multiple futures, the scenario technique paradigmatically differs from predictive or forecasting methodologies such as Delphi studies [155] or prediction markets [156] whose outcome could be seen as the single, most probably scenario neglecting other potential future developments. The scenario technique can also be used in conjunction with other techniques such as environmental scanning [128], identifying weak signals [4, 69], or roadmapping [162].

Just like the strategy process, also the scenario process is a sequenced process (Fig. 1). After the scenario development process in the narrow sense is completed, the determined scenarios feed into the further scenario use phase [134], i.e., the organization's strategy process, namely strategy development and, later, execution [110]. Apart from employing scenario techniques, organizations can also consider externally given scenarios such as those offered by Atherton for small businesses [6].

Whereas most strategy tools have a selective effect by stressing what to focus on and what to neglect [77], the scenario technique does not narrow but instead expands the focus of attention. The method commonly used in firms to cope with this multiplicity of possible future developments is to identify the relevant scenarios and to assign the specific probabilities of occurrence to existing scenarios. This is in line with risk management [9], which is also very common in firms and, fundamentally, is based on probabilistic thinking. However, this probabilistic approach corresponds to the rather outdated positivist paradigm in futures research, which has been complemented by newer paradigms in the last four decades $[67,152]$. In this sense, most organizations concentrate on the scenarios with the highest probabilities or the best-case, the worst-case, and an average scenario. Fewer organizations also consider scenarios with minor probabilities. These "black swans" [151] or "wild cards" [106] have diminutive probabilities but would have major (negative) consequences if they occurred and, therefore, should also be considered if possible.

From the perspective of the practice-based view of strategy [24], firms that make use of the scenario technique are supposed to perform better than those that do not. Indeed, the scenario technique should have such a positive effect on the overall firm performance [102]. Phelps et al. [118] even see an improved financial performance resulting from the use of scenarios. However, their observations are based on two exploratory studies only. In contrast, Augier et al. [7] did not find empirical evidence to support the long-term relationship between the use of scenarios and financial firm performance. For them, these benefits would clearly appear only over longer time horizons. Even if an influence on financial performance is hard to measure, an improvement in sustaining organizational development by using scenarios rather than prediction techniques can be attested [160].

\section{Constraints}

Constraints are limits in the use of scenarios as a strategy tool, and therefore, no sub-type of affordances, but rather their opposite. However, both scholars and practitioners have to inquire not only the possibilities offered by a tool, but also its restrictions [77]. As the whole strategy process is being influenced by cognition and behavior $[59,83,107$, $111,125]$, so is the scenario process. Especially, participants in the scenario process are confronted with the constraints of bounded rationality, biased cognition, and their ontological assumptions about the future.

\section{Bounded rationality}

Even though the scenario technique is a rational way to cope with uncertainty, its users are subject to bounded rationality [122, 143]. First, due to limited cognitive capabilities, not all possible relevant information can feed into the scenario development process [140] and not every conceivable scenario can be explored and considered. Certainly not all strategists can anticipate competitors' behaviors [94]. Even highly developed foresight skills do not ensure that all the pertinent future scenarios will be appropriately considered. "Weak signals" $[4,69]$ are often so attenuated that they are barely perceptible. Prior long-term trends do not reveal their discontinuities and disruptions in advance. While black swans or wild cards are, irrespective of their low probabilities, at least imaginable, no decision maker can preempt "unknown unknowns" [50]. Not even the preconditions for the occurrence of the yet feasible event can be known. For example, in the 1960s, the issue of data protection in social networks was unimaginable since there was a mass market neither for personal computers, tablets, or smartphones, nor for social network platforms.

Second, due to uncertainty, the calculation and assignment of probabilities to future scenarios is problematic. Empirical research shows that managers prefer risk in the face of known probabilities rather than ambiguity where there are unknown ones [46]. Individuals are not comfortable with uncertainty and, therefore, they try to substitute it with risk. This aversion to ambiguity leads to the preference for the probabilistic management of future scenarios. However, likelihood estimations can be deduced as a second-order prediction rather than the result of a proper calculation. What the future may resemble is a prediction of content, while a statement about 
its likelihood is a prediction of form. Therefore, the problematic prediction of the future is pseudo-simplified by the problematic prediction of its likelihood.

\section{Biased cognition}

Another constraint of the scenario technique is the fact that (future) situations are subject to interpretation [84]. Individuals participating in scenario workshops have diverse interpretations [54] and are exposed to multiple cognitive biases $[66,107]$. While the scenario technique reduces the framing bias in decision making [105], overconfidence, and tunnel vision [139], scenario planners can suffer from other biases such as selective attention as they unintentionally focus on specific scenarios and neglect others. Such information processing filters in the process of environmental analysis can especially be formed by personal experiences, values, and personalities [63]. These biases do not only occur for the assessment of current but also for future situations as it is negligible whether the mental imagery refers to the present, the past, counterfactual pasts-or just imaginative futures [1, $21,91,138,150]$. Humans have the capability for mental time travel [148] based on their episodic memory and autonoetic consciousness, i.e., the ability to mentally place oneself in real or imagined situations [55]. Consequently, top managers will construct and focus on future scenarios that align with their personal experiences, values, and personality traits. These effects are also observed when top managers delegate the scenario development process to foresight professionals because, according to the wishful-thinking premise, they tend to forecast what the employer wishes to hear [5].

First, personal experiences as parts of an individual's episodic memory form future expectations [138] and retrospective sensemaking affects the way new situations are interpreted [167]. Individuals usually expect things to occur similarly as they did before and, in turn, other developments and outcomes tend to be ignored. Therefore, history forms a lens through which the future is viewed and only those future scenarios are considered that are consistent with the company's history [84]. According to Berg Johansen et al. [16], especially in capitalist societies, managers do not tend to view the future as open but expect the future to be similar to their prior personal experiences. Relevant personal experiences include work as well as private experiences and can have major impacts on perception. For example, the death of a dear friend or family member by cancer can generally lead to a perspective away from the present and toward the longer term [96].

Second, values have a strong influence on cognition and behavior [98, 141]. They can also have a strong filtering effect since scenarios are not considered impartially as textually equivalent but are separated into preferred and preventable ones. Additionally, the degree of preference might also influence subjective or outweigh objective probabilities, respectively.

Third, personality traits influence information processing $[93,136]$. One's openness disposition appears especially relevant among all personality traits. It determines managers' readiness to engage with multiple scenarios rather than just a few of them or even a single one [28]. Furthermore, the mental attitude, even if to be distinguished from traits to facilitate precision, affects the kinds of scenarios that will attract particular attention. It can be assumed that optimistic, hopeful, or courageous managers will focus more on positive scenarios, while rather pessimistic, hopeless, or anxious managers have a stronger tendency to focus more on negative ones.

Not only the scope and content of future scenarios are exposed to biased cognition, so is the estimation of their likelihood. This finding is supported by the notion of subjective probabilities. Without reliable information, actors have to calculate probabilities of events based on prior experiences. Consequently, they are dependent on several influences such as personality and motivation [47], belief [144], mood [173], loss aversion [17], or cultural background [166]. Additionally, since subjective probabilities and choices have to be conceptually differentiated $[80,165]$, the future scenario with the highest subjective probability need not be the one that is selected as the basis for further strategy development.

\section{Ontological assumptions about the future}

Finally, another constraint of the scenario technique lies in individuals' beliefs about the concept of "future" that can affect the construction and selection of future scenarios. For example, many futurists still see the future as a solely cognitive concept and neglect that future developments have a latent connection to the present reality [121], which, in turn, is rooted in the past [154]. However, while in a purely cognitive conceptualization "anything goes," scenarios more strictly anchored in current reality structures are necessarily more restricted in their range.

Another belief about the ontology of the future relates to its controllability: Crilly [38] found that, compared with an ego-moving frame ("we are approaching the future") along with an external locus of control, a time-moving framework ("the future is approaching") alongside an internal locus of control [71, 132] leads to a long- rather than short-term orientation. Therefore, an individual's specific personality has an influence on whether rather short- or long-term changes are considered.

Further ontological beliefs might have an influence on the scope and content of future scenarios, which should be tested by future empirical studies. For example, the assumed degree of the openness of the future has an influence on the number and scope of scenarios to be 
considered. If the future is expected to be more or less predetermined, vast deviations from current trends are seen as less probable and, therefore, less taken into consideration. Scenario planners with a rather voluntarist worldview would have to assess the impact of different influencer groups on possible future developments. In contrast, scenario planners who believe in pure chance as the main driver of future development would not consider human influences.

Relatedly, the degree of foreseeableness imbued in the process leads to decisions regarding the number and scope of scenarios. Whereas openness addresses the ontology of the future, foreseeableness addresses the corresponding epistemology. If the future is seen to be predictable, a main scenario with a high probability attracts most attention or other scenario will not be considered at all, hence, making the use of the scenario technique obsolete. In contrast, if the future is seen as forecastable, multiple scenarios with distinct probabilities can be considered. In a situation of "true ambiguity" [37], a broad scope of scenarios with no distinct probabilities have to be considered.

\section{Hidden effecter affordances}

Hidden effecter affordances address additional benefits that can be gained from the use of scenarios that go beyond its original purpose. They can be grouped into strategy- and organization-related affordances.

\section{Strategy-related effecter affordances}

Positive side-effects of the scenario technique along the whole strategy process can be found in the literature. First, the scenario technique can foster strategic analytical thinking [19]. It can contribute to more focused attention being placed on environmental dynamics [124]. While traditional external analysis focuses on present macro forces, viewing the industrial structure influencing the organization as being rather static, a foresightoriented perspective stimulates procedural thinking. Scenario planners consider possible future event-chains fostering their understanding of causal processes in the environment. By doing so, they have to consider a plethora of external, non-isolated but rather interconnected elements that fosters complex and systemic thinking.

Second, in the strategy development phase, not only one or a few, but numerous strategic options are made transparent. This clarity of distinguishable alternative courses of action improves strategic decision making [31, 33, 112]. Meissner and Wulf [105] stress that the scenario technique reduces the framing bias in decision making and, therefore, enhances decision quality. The quality of strategic decisions is also improved as their robustness is systematically tested [160]. Unlike an optimal decision that is adequate for the anticipated single-mostprobable future development, a robust decision has to fit multiple different future developments. Robust rather than optimal decision making is no less of a paradigm shift that challenges conventional economic thinking. As a result of these hidden affordances, the scenario technique generally enhances the participants' strategy development capabilities [102].

Third, using scenarios raises the likelihood that not any strategy is formulated but especially an innovation strategy [172]. The divergent rather than convergent practice of the scenario technique can be associated with creativity that also involves the integration of paradoxes. Indeed, Chermack et al. [32] found that the scenario technique enhances a creative climate in organizations. The foresight perspective frees participants from present restrictions, opens their minds for new solutions, and fosters intuition [34]. Therefore, the scenario technique can be seen as a tool for strengthening innovation and corporate entrepreneurship [40, 172]. Strategic foresight contributes to both explorative and exploitative innovations and, thus, is a tool of organizational ambidexterity [114].

Fourth, also the strategic implementation phase can benefit from the scenario technique. The clear distinction between alternative strategic options during strategy development involves clarity for each option individually. As the managers have a clear picture about what has to be done, this increases their strategy execution capability [102]. The scenario development process also has a motivating effect on its participants, increasing their engagement to mobilize forces and resources [26, 160].

Fifth, strategic implementation can necessitate strategic change, especially when participants expect future developments that significantly differ from the present situation. By considering multiple divergent scenarios, existing assumptions about the environment are challenged [33, 160]. Managers are forced to reframe their perceptions and change existing organizational mental models [126]. The required strategic change can be facilitated by the scenario technique because managers can introduce new discursive statements to their subordinates [64]. These can inspire actions and pave the way for new structures that are necessary for upcoming challenges [40]. In this way, beaten organizational paths can be broken $[149,154]$. Several authors also emphasize the relationship between the use of the scenario technique and individual and organizational learning $[18,20,33$, $102,112,126]$. This learning process refers to specific scenarios, especially surprising ones [56] and, more abstractly, the aforementioned analytic capabilities such as understanding the complexity and dynamics of environmental change, making sense of it, and drawing sensible conclusions. It also refers to a non-empirical learning style that relates possible future events with possible organizational reactions and their anticipated success 
[18]. This thought-experiment-like learning fosters strategic thinking ability [126].

\section{Organization-related effecter affordances}

Apart from the hidden strategy-related affordances, the scenario technique also results in several positive sideeffects at the organizational level, especially regarding organizational behavior. As scenario development is usually a practice that involves the participation of several organizational members, communication [89], and especially strategic conversation between them is facilitated [160], and its quality rises [35]. With scenarios being complex future configurations involving much specific information and specialist expertise from different functions and departments, this strategic conversation is not limited to a single management level but rather forges a cross-level and cross-functional communication process throughout the organization [73, 75, 99, 102, 115]. As people connect and exchange views across functions and departments [19], group cohesion [89], and motivations rise [26, 160]. Even without consensus, organizations benefit from these social interactions [171]. However, more often than not, a common perspective can be developed [160].

\section{Hidden handling affordances}

Hidden handling affordances allow an organizational member to gain personal benefits. Regarding organizational goals, they can be either indifferent or conflicting. Therefore, the usefulness of the scenario technique as a strategy tool cannot only be measured in terms of organizational performance but also the degree to which actors may achieve their personal goals [77]. In that sense, not only the strategy process $[11,45,83,99,108,109,116,133]$ or strategic discourses $[10,65]$ in general are political processes, but also the scenario development and communication process in particular.

\section{Selection of scenario process participants}

Strategy practices have an influence on performance and other outcomes. This insight is shared by both the strategyas-practice school $[68,79,159,168,169]$ and the practicebased view of strategy [24]. Against this background, the selection of a specific strategic tool may already be influencing the whole strategy process. In particular, strategy tools might merely be used to give the impression of rationality [51] and to support an already predetermined decision [77]. Therefore, choosing the scenario technique has already become a political decision in such circumstances.

The selection of the method goes hand in hand with the selection of those who (can) use the method. By whom a strategy tool is used makes a difference [78]. For example, different outcomes from applying a specific strategy tool were observed depending on whether practitioners were top or middle managers [11, 52], internal employees, or external strategy consultants [101, 104]. Additionally, departmental membership and, therefore, functional focus played a crucial role [60].

For strategic foresight, several methodologies are at the organization's disposal, the scenario technique being a prominent one, albeit not the only available method. As the affordances offered by a tool also depend on the skills an actor has [127], the choice for the scenario technique can have a selective effect that includes managers who are experienced in this methodology and excludes those who are not. Additionally, as scenarios can be developed via different specific foresight methods [117], also the selection of the concrete method can restrict further the number of managers to those who have the skills to apply this method.

However, the selection of participants from the scenario development process is not necessarily based on expertise alone, but may be seen as an act of wielding power. Especially middle management consists of many experts with pieces of the relevant detailed knowledge needed to discover probable future developments [39], highly relevant for the scenario development process. Nevertheless, their special knowledge does not automatically make them participants in scenario development.

\section{Execution of scenario development}

How practices are performed also makes a difference [78]. Therefore, managers participating in the scenario-planning process have the power to directly influence the scenario development- and, therefore, the whole strategy process. They can control the way the tool is used, and which outcomes are and are not produced [11, 99, 133]. Apart from this exertion of power, also their power base can be strengthened by demonstrating their competence and fostering their reputation in the organization $[77,103]$.

Strategic work in general and scenario development in particular can be conducted in a private, collaborative, or negotiated way [76]. When scenarios are developed privately, the outcome of this process can be directly influenced by the individuals or group of organizational elites in charge, promoting their specific agendas. Collaborative or participative scenario development, as most commonly conducted in scenario workshops, attempts to include and unite multiple contradicting views [3, 123], but it hardly assures that all views are represented equally. Rather, this aspect may be regarded as a negotiating process where different views compete for consideration [134]. This view is in line with social constructionist perspectives which conceptualize the emergence of images of the future as the result of a social negotiation process $[53,153]$. In strategy workshops in general, and scenario development workshops in particular, group dynamics emerge from mutual behaviors [51] and emotions [95]. These dynamics 
do not necessarily unfold by accident alone but can, in part, be deliberately influenced or manipulated.

\section{Communicating scenarios in the strategy development process} As scenario development provides the informational foundation for the subsequent strategy formation, controlling this process constitutes a significant power base. Strategizing is not only an interpretative process of sensemaking, i.e., trying to understand the given and possible future situations and options for today's strategic action [83, 84, 90, 167] but also a process of sensegiving, i.e., communicating this subjective interpretation to others [43, 62, 112].

Especially when strategists did not participate in the scenario development process on their own, they have to familiarize themselves with the predetermined scenarios before they can feed them into the further strategy process [110]. This "handing over" of scenarios, as the output of the scenario development process and the input for the subsequent strategy development process, can offer opportunities for political interventions.

In particular, scenario developers can emphasize or even develop a specific scenario that best supports their goals and omits the communication of scenarios contradicting their personal agendas. When, as usual, multiple scenarios are created, the preferred one can be presented in a favorable or convincing way.

In presenting scenarios, the specific use of language plays an important role, as language, in general, has a strong impact on strategizing to reach desired outcomes [12, 133, 137]. For example, extreme scenarios suggest selfconfidence in forecasting which has a convincing effect on others [5]. Similarly, precise forecasts, even when precision is not based on accurate calculations, imply expertise [97] and, therefore, have a persuasive effect. Concrete numbers can especially give the impression of rationality [42].

Developing a scenario can be seen as constructing a strategic narrative [22, 25, 84]. Different forms of narratives have different effects on recipients $[43,56]$. For example, Sonenshein [145] distinguished between progressive, regressive, and stability narratives. Future scenarios can take either of these forms depending on the scenario being presented as better than the present, similar to the past, or not too different from the present.

The effect of narratives depends especially on their affective impact [137]. Thus, a narratively presented scenario can evoke strong emotions among recipients [95] fostering their attention, motivation, and commitment in the further strategy process. Individuals will support the scenario according to its specific emotional impact on them. However, the emotional effect is not obvious. Extensive research exists pertaining to affective forecasting, dealing with the prediction of one's feelings in the future and their impact on decision making and behavior [170]. In contrast, emotions arising from thinking about or visualizing the future is an emerging research field. In this sense, Baumgartner et al. [15] distinguish between "anticipated" emotions expected to be experienced in the future and "anticipatory" emotions experienced in the present in the context of future thought. An attempt to understand the emotional and motivational effect of future scenarios can be the hedonistic principle of promotion and prevention, that is, approaching pleasure and avoiding pain [68]. Primarily, anticipation is somewhat optimistic when the future represents an opportunity, while it is rather pessimistic when the future is seen as a threat. Individuals are motivated to realize a preferred future, especially when they believe it is achievable [164], to adapt to their expected future, or to prevent an unpleasant one. However, it is uncertain if hedonistic principles can explain future-oriented behavior directly and unequivocally. Rather, it is unclear which patterns of action will be provoked. Scenarios that evoke positive emotions might motivate organization members to either engage in the realization of these favorable scenarios or, in contrast, reduce their efforts since they expect the future scenario to come true regardless of their own commitment. In turn, scenarios which include a possible future threat and, therefore, evoke negative emotions, can substantially motivate employees to prevent it from happening and lead to appropriate organizational responses [29]. Such scenarios, therefore, can be expected to have a stronger effect on an individual's psychological state than scenarios that evoke positive emotions [82, 135, 158]. However, instead of provoking increased countermeasures to avoid the unfavorable future to come true, contrarily, resignation, absenteeism, or fluctuation could also occur instead. Moderator variables that make the difference might be the perceived extent of control [71, 132], even if it is illusory [44], and the perception that effort will lead to achieving intended outcomes [157]. Additionally, it can be assumed that moderately positive or negative scenarios will have different results than extreme scenarios. Hence, the functional correlation might be an inverted U-shaped curve. Such hypotheses can be tested in future empirical studies.

Apart from the content of the scenarios, their probabilities can be manipulated, too. Probabilities of favorable scenarios may be raised or the probabilities of unfavorable ones may be diminished. In fact, managers need not make their case with probabilities at all, but can confine their statements to items of relevance alone or present their preferred future scenario as the only one possible, without alternatives.

It is important to acknowledge the political dimension of the scenario technique, as manipulated scenario processes can have severe consequences on the organization. Following the notion of "garbage in, garbage out," distorted 
scenarios that foster individual careers and power bases can obviously lead to poor strategic choices and flawed and misleading strategy. Consequently, competitive disadvantages might arise, wherein even the survival of the firm is threatened.

As mentioned before, hidden handling affordances primarily address individual outcomes and affect organizational outcomes only indirectly. In particular, by manipulating the scenario and strategy processes, the influencer tries to promote his or her personal goals, such as career goals. However, this does not imply that the political actor necessarily provides "false" scenarios, especially as scenarios are not supposed to be predications which, later, can prove to be true or false. Rather, the manipulator might select or stress scenarios that are or are not useful for the organization.

\section{Discussion}

Managers use the scenario technique not only in its intended sense, and this aberration does not always work out. A view that concentrates on the solely rational side of the method alone-developing multiple scenarios to improve strategy development under conditions of high uncertainty-is necessarily limited. By taking an affordancebased view on the scenario technique, it is possible to see the full range of possibilities and constraints of this method that also goes beyond its original idea. Table 1 summarizes the affordances discussed in the paper, which does not claim to be exhaustive but rather represents the body of knowledge concluded from prior research.

The main contribution of this paper is to develop a framework that distinguishes between different possibilities and constraints offered by the scenario technique as a foresight and strategy method. By distinguishing between effecter and handling affordances, it draws attention not only to organizational, but also individual purposes that can be pursued by using scenarios. The affordance-based view can also be applied to strategic foresight in general. Therefore, the paper draws attention to emergent organizational phenomena arising from future-oriented thinking in a broader sense.

\section{Implications for research}

The paper has several implications for future research regarding both the scenario technique in particular and strategic foresight in general. First, the scope of research should be expanded to side-effects of strategic foresight in general. Both positive and negative side-effects have been discussed in the paper. However, these were derived from an affordance-based view pertaining to the scenario technique alone. Further side-effects apart from affordances and the scenario technique as a specific foresight method should be identified. For example, Burt et al. [27] discussed "managerial hyperopia," the neglect of short-term issues, as negative side-effects of strategic foresight. Research on such side-effects is helpful as understanding them is the prerequisite for a targeted use of foresight tools.

Second, it opens further the black box why firms using the scenario technique might be more successful than firms that do not. The scenario technique is seen as a method that has a positive impact on firm performance $[102,118,160]$. However, the causal links are unclear. Apart from a direct effect of using scenarios on enhanced firm performance, the affordance-based view calls attention to an indirect mechanism. One's view about hidden effecter affordances in particular presents several proposals for moderator variables. For example, using scenarios contributes to group cohesion (Langley, 1989), group cohesion contributes to group performance [48], and group performance assumingly contributes to firm performance. Similar causal links can be found for other hidden effecter affordances. Future empirical

Table 1 Full range of affordances of scenario planning. Source: author

\begin{tabular}{|c|c|}
\hline Intended effecter affordance & Constraints \\
\hline $\begin{array}{l}\text { - Dealing with uncertainty and ambiguity } \\
\text { - Assessment of multiple possible future scenarios } \\
\text { - Enhancing firm performance }\end{array}$ & $\begin{array}{l}\text { - Bounded rationality: lack of information; impossible consideration } \\
\text { of all possible scenarios; unclear probabilities, ... } \\
\text { - Biased cognition: selective attention, subjective interpretations, and } \\
\text { biased probability estimates due to personal experiences, values, } \\
\text { and personality traits, ... } \\
\text { - Beliefs about the future: ego- or time-moving frame; locus of control; } \\
\text { openness of the future; determinist, voluntarist, or pure-chance-worldview; } \\
\text { foreseeableness of the future, ... }\end{array}$ \\
\hline Hidden effecter affordances & Hidden handling affordances \\
\hline $\begin{array}{l}\text { - Strategy-related: fostering attention to environmental dynamics; } \\
\text { fostering analytic, procedural, causal, complex, and systemic thinking; } \\
\text { improving decision making (quality); raising probability for an } \\
\text { innovation strategy; improving strategy execution; enabling } \\
\text { strategic change and organizational learning, ... } \\
\text { - Organization-related: fostering cross-level and cross-functional } \\
\text { communication; improving group cohesion and motivation, ... }\end{array}$ & $\begin{array}{l}\text { - Selection of scenario planning participants: including and excluding } \\
\text { specific scenario developers, ... } \\
\text { - Execution of scenario planning: private, collaborative, or negotiating } \\
\text { execution, ... } \\
\text { - Feeding scenarios into the strategy development: over- and } \\
\text { underemphasizing scenarios and their probabilities, ... }\end{array}$ \\
\hline
\end{tabular}


research on the impact of using scenarios on firm performance should include such mediator variables.

Third, the presented view can be expanded to futurerelated thinking in general. It can be expected that not only the use of foresight methods, but also other futurerelated phenomena might have unintended effects for the organization. For example, inspiring visions, as mental images of appealing and realistic future situations, have a positive effect on motivation and individual and group performance [14, 86, 142, 147]. Similarly, mission statements, as statements about the intent to reach a future state, contribute to an increased organizational commitment and overall firm performance [13]. Which further positive and negative side-effects might such visions and mission statements have? Future-related perceptions, values, and behaviors can also be implicit or explicit parts of the organizational culture. For example, it can manifest the relevance of strategic foresight or the will to change the future. Little research has been conducted on the relationships between strategic foresight and organizational culture. Yet, for example, Korte and Chermack [88] explored how scenarios can be used to change organizational culture. Further interesting research questions include: How are-and how can-explicitly future-oriented cultures be formed? Which direct and indirect effects do future-oriented cultures have on performance? An interesting starting point might be the work of Polak [120] who investigated the relationship between imagined societal futures and cultural development throughout several centuries of human history and posited that mental images about the future have, among several other factors, an influence on human behavior.

Finally, the classification and framework of affordances presented in this paper draws attention not only to the possibilities offered by the scenario technique in particular and strategic foresight in general, but also on their constraints. The scenario technique is a tool developed to handle uncertainties. The constraints discussed in the paper show that the degree to which this purpose can be achieved depends on several aspects. Further research on the constraints of the scenario technique and foresight can help address weaknesses in executing these techniques.

\section{Implications for practice}

The affordance-based view also has general, practical implications for the scenario technique and strategic foresight. First, mastering the constraints of the scenario technique is not limited to academic research but can also be pursued in managerial practice. For example, several cognitive biases can be overcome or at least be reduced by the actors' increased awareness. When the participants of a scenario development workshop know the risk of selective attention, they can actively take countermeasures and broaden the directions of their attention.
Second, hidden effecter affordances lead to several positive side-effects that may be actively evoked in circumstances relevant for other-than-strategy purposes. For example, human resource managers can use the scenario technique as a leadership development tool [103] or team leaders can use it as a team building tool [89] even if the development of scenarios was not intended per se.

Third, the discussion of hidden handling affordances showed significant risks evoked by pursuing individual interests differing from organizational goals. Knowing these risks can help managers by depoliticizing the scenario development and communication processes. To ensure a broad scope of accurate scenarios, managers from all relevant departments should be included and scenarios should be developed collaboratively and communicated equally.

\section{Conclusion}

The scenario technique is not only a well-defined method with a rational organizational purpose, but also a tool-in-use with emergent attributes. This paper draws on an affordance-based view and identifies intended effecter affordances, hidden effecter affordances, and hidden handling affordances as well as constraints of the scenario technique. The relational conceptualization of affordances as an attribute "between" the actor and the tool stresses that not all possible attributes of scenario planning are always applicable, but their emergence depend on the context, especially who participates in the process with what intentions.

A framework of the affordances and constraints of the scenario technique was suggested that allows for the identification of the full range of the multiple facets of the scenario technique and how they relate to different purposes. The framework was used to structure the empirical and theoretical insights from extant research on the scenario technique, strategic foresight, and strategic management.

By doing so, it especially expands the research scope of the scenario technique and calls for a research agenda that also focuses on affordances and constraints beyond the intended ones. The paper likewise contributes to managerial practice by raising awareness for nonforesight-related purposes, cognitive and behavioral restrictions, and the risks of political misuse.

The paper seeks to inspire future research on hidden attributes of the scenario technique also based on other conceptualizations in order to open the black box of the link between the use of the scenario technique and firm performance. It would be especially interesting to identify mediator variables. The affordance-based view could also be applied to other future-related phenomena such as visions, mission statements, or organizational cultures. 


\section{Acknowledgements}

I would like to thank David Mackay, University of Stirling, Nele Fischer, the journal's managing editor, and two anonymous reviewers for their valuable and constructive comments on prior versions of this paper.

\section{Author's contributions}

The sole author wrote and revised the manuscript. The author read and approved the final manuscript.

\section{Funding}

The APF was funded by the Deutsche Forschungsgemeinschaft (DFG) and the Open Access Publishing Fund of University of Potsdam. I gratefully acknowledge their support.

\section{Availability of data and materials}

Not applicable.

\section{Ethics approval and consent to participate}

Not applicable.

\section{Consent for publication}

The author agrees to publish.

\section{Competing interests}

The author declares that he has no competing interests.

Received: 1 August 2019 Accepted: 6 December 2019

Published online: 30 December 2019

\section{References}

1. Addis DR, Wong AT, Schacter DL (2007) Remembering the past and imagining the future: common and distinct neural substrates during event construction and elaboration. Neuropsychologia 45:1363-1377. https://doi. org/10.1016/j.neuropsychologia.2006.10.016

2. Anderson J (1997) Technology foresight for competitive advantage. Long Range Plan 30:665-677. https://doi.org/10.1016/S0024-6301(97)00052-6

3. Andreescu L, Ghorghiu R, Zulean M, Curaj A (2013) Understanding normative foresight outcomes: scenario development and the 'veil of ignorance' effect. Technol Forecast Soc Change 80:711-722. https://doi.org/ 10.1016/j.techfore.2012.09.013

4. Ansoff HI (1975) Managing strategic surprise by response to weak signals. Calif Manag Rev 18:21-33. https://doi.org/10.2307/41164635

5. Ashiya M (2009) Strategic bias and professional affiliations of macroeconomic forecasters. J Forecast 28:120-130. https://doi.org/10.1002/for.1095

6. Atherton A (2005) A future for small business? Prospective scenarios for the development of the economy based on current policy thinking and counterfactual reasoning. Futures 37:777-794. https://doi.org/10.1016/j. futures.2005.01.002

7. Augier M, Dew N, Knudsen T, Stieglitz N (2018) Organizational persistence in the use of war gaming and scenario planning. Long Range Plan 51:511525. https://doi.org/10.1016/j.lrp.2017.12.005

8. Ayres RU, Axtell R (1996) Foresight as a survival characteristic: when (if ever) does the long view pay? Technol Forecast Soc Change 51:209-235. https:// doi.org/10.1016/0040-1625(95)00212-X

9. Baird IS, Thomas H (1985) Toward a contingency model of strategic risk taking. Acad Manag Rev 10:230-244. https://doi.org/10.2307/257965

10. Balogun J, Jacobs C, Jarzabkowski P, Mantere S, Vaara E (2014) Placing strategy discourse in context: sociomateriality, sensemaking, and power. J Manag Stud 51:175-201. https://doi.org/10.1111/joms.12059

11. Balogun J, Johnson G (2004) Organizational restructuring and middle manager sensemaking. Acad Manag J 47:523-549. https://doi.org/10.5465/ 20159600

12. Barry D, Elmes M (1997) Strategy retold: toward a narrative view of strategic discourse. Acad Manag Rev 22:429-452. https://doi.org/10.5465/AMR.1997. 9707154065

13. Bart CK, Bontis N, Taggar S (2001) A model of the impact of mission statements on firm performance. Manag Decis 39:19-35. https://doi.org/10. 1108/EUM0000000005404

14. Baum JR, Locke EA, Kirkpatrick SA (1998) A longitudinal study of the relation of vision and vision communication to venture growth in entrepreneurial firms. J Appl Psychol 83:43-54. https://doi.org/10.1037/0021-9010.83.1.43
15. Baumgartner H, Pieters R, Bagozzi RP (2008) Future-oriented emotions: conceptualization and behavioral effects. Eur J Soc Psychol 38:685-696. https://doi.org/10.1002/ejsp.467

16. Berg Johansen C, De Cock C (2017) Ideologies of time: how elite corporate actors engage the future. Organ 25:186-204. https://doi.org/10.1177/ 1350508417725592

17. Bilgin B (2012) Losses loom more than gains: propensity to imagine losses increases their subjective probability. Organ Behav Hum Decis Process 118 : 203-215. https://doi.org/10.1016/j.obhdp.2012.03.008

18. Bingham CB, Kahl S (2014) Anticipatory learning. Strateg Entrep J 8:101-127. https://doi.org/10.1002/sej.1166

19. Boe-Lillegraven S, Monterde S (2015) Exploring the cognitive value of technology foresight: the case of the Cisco Technology Radar. Technol Forecast Soc Change 101:62-82. https://doi.org/10.1016/j.techfore.2014.07.014

20. Bootz JP (2010) Strategic foresight and organizational learning: a survey and critical analysis. Technol Forecast Soc Change 77:1588-1594. https://doi.org/ 10.1016/j.techfore.2010.06.015

21. Botzung A, Denkova E, Manning L (2008) Experiencing past and future events: functional neuroimaging evidence on the neural bases of mental time travel. Brain Cogn 66:202-212. https://doi.org/10.1016/j.bandc.2007.07.011

22. Bowman G, MacKay B, Masrani S, McKiernan P (2013) Storytelling and the scenario process: understanding success and failure. Technol Forecast Soc Change 80:735-748. https://doi.org/10.1016/.techfore.2012.04.009

23. Bradfield R, Wright G, Burt G, Cairns G, van der Heijden K (2005) The origins and evolution of scenario techniques in long range business planning. Futures 37:795-812. https://doi.org/10.1016/j.futures.2005.01.003

24. Bromiley P, Rau D (2014) Towards a practice-based view of strategy. Strateg Manag J 35:1249-1256. https://doi.org/10.1002/smj.2238

25. Brown AD, Thompson ER (2013) A narrative approach to strategy-as-practice. Bus Hist 55:1143-1167. https://doi.org/10.1080/00076791.2013.838031

26. Brunsson N (1982) The irrationality of action and action rationality: decision, ideologies and organizational actions. J Manag Stud 19:29-44. https://doi. org/10.1111/j.1467-6486.1982.tb00058.x

27. Burt G, Mackay DJ, Perchard A (2015) Managerial hyperopia: a potential unintended consequence of foresight in a top management team? Technol Forecast Soc Change 101:134-146. https://doi.org/10.1016/j.techfore.2013.12.001

28. Burt G, Mackay DJ, van der Heijden K, Verheijdt C (2017) Openness disposition: readiness characteristics that influence participant benefits from scenario planning as strategic conversation. Technol Forecast Soc Change 124:16-25. https://doi.org/10.1108/EJTD-08-2015-0068

29. Chattopadhyay P, Glick WH, Huber GP (2001) Organizational actions in response to threats and opportunities. Acad Manag J 44:937-955. https:// doi.org/10.5465/3069439

30. Chemero A (2003) An outline of a theory of affordances. Ecol Psychol 15: 181-195. https://doi.org/10.1207/S15326969ECO1502_5

31. Chermack TJ (2004) Improving decision-making with scenario planning. Futures 36:295-309. https://doi.org/10.1016/S0016-3287(03)00156-3

32. Chermack TJ, Coons LM, Nimon K, Bradley P, Glick MB (2015) The effects of scenario planning on participant perceptions of creative organizational climate. J Leadership Organ Stud 22:355-371. https://doi.org/10.1177/ 1548051815582225

33. Chermack TJ, Lynham SA (2002) Definitions and outcome variables of scenario planning. Hum Resour Dev Rev 1:366-383. https://doi.org/10.1177/ 1534484302013006

34. Chermack TJ, Nimon K (2013) Drivers and outcomes of scenario-planning: a canonical correlation analysis. Eur J Training Dev 37:811-834. https://doi. org/10.1108/EJTD-03-2013-0030

35. Chermack TJ, van der Merwe L, Lynham SA (2007) Exploring the relationship between scenario planning and perception of strategic conversation quality. Technol Forecast Soc Change 74:379-390. https://doi.org/10.1016/j. techfore.2006.03.004

36. Clegg SR, Carter C, Kornberger M (2004) Get up, I feel like being a strategy machine. Eur Manag Rev 1:21-28. https:/doi.org/10.1057/palgrave.emr.1500011

37. Courtney H, Kirkland J, Viguerie P (1997) Strategy under uncertainty. Harvard Bus Rev 75:67-79

38. Crilly D (2017) Time and space in strategic discourse: implications for intertemporal choice. Strat Manag J 38:2370-2389. https:/doi.org/10.1002/smj.2687

39. Darkow IL (2015) The involvement of middle management in strategy development-development and implementation of a foresight-based approach. Technol Forecast Soc Change 101:10-24. https://doi.org/10.1016/ j.techfore.2013.12.002 
40. de Smedt P, Borch K, Fuller T (2013) Future scenarios to inspire innovation. Technol Forecast Soc Change 80:432-443. https://doi.org/10.1016/j.techfore. 2012.10.006

41. Demir R (2015) Strategic activity as bundled affordances. Brit J Manag 26: S125-S141. https://doi.org/10.1111/1467-8551.12083

42. Denis JL, Langley A, Rouleau GA (2006) The power of numbers in strategizing. Strateg Organ 4:349-377. https://doi.org/10.1177/ 1476127006069427

43. Dunford R, Jones D (2000) Narrative in strategic change. Hum Relat 53: 1207-1226. https://doi.org/10.1177/0018726700539005

44. Durand R (2003) Predicting a firm's forecasting ability: the roles of organizational illusion of control and organizational attention. Strat Manag J 24:821-838. https://doi.org/10.1002/smj.339

45. Eisenhardt KM, Bourgeois LJ III (1988) Politics of strategic decision making in high-velocity environments: toward a midrange theory. Acad Manag J 31: 737-770. https://doi.org/10.5465/256337

46. Ellsberg D (1961) Risk, ambiguity, and the savage axioms. Q J Econ 75:643669. https://doi.org/10.2307/1884324

47. Eroglu C, Croxton KL (2010) Biases in judgmental adjustments of statistical forecasts: the role of individual differences. Int J Forecast 26:116-133. https://doi.org/10.1016/j.ijforecast.2009.02.005

48. Evans CR, Dion KL (1991) Group cohesion and performance: a meta-analysis. Small Group Res 22:175-186. https://doi.org/10.1177/1046496491222002

49. Fayard AL, Weeks J (2007) Photocopiers and water-coolers: the affordances of informal interaction. Organ Stud 28:605-634. https://doi.org/10.1177/ 0170840606068310

50. Feduzi A, Runde J (2014) Uncovering unknown unknowns: towards a Baconian approach to management decision-making. Organ Behav Hum Decis Process 124:268-283. https://doi.org/10.1016/j.obhdp.2014.04.001

51. Feldman MS, March JG (1981) Information in organizations as signal and symbol. Adm Sci Q 26:171-186. https://doi.org/10.2307/2392467

52. Floyd SW, Lane PJ (2000) Strategizing throughout the organization: managing role conflict in strategic renewal. Acad Manag Rev 25:154-177. https://doi.org/10.2307/259268

53. Fuller T, Loogma K (2009) Constructing futures: a social constructionist perspective on foresight methodology. Futures 41:71-79. https://doi.org/10. 1016/j.futures.2008.07.039

54. Franco LA, Meadows M, Armstrong SJ (2013) Exploring individual differences in scenario planning workshops: a cognitive style framework Technol Forecast Soc Change 80:723-734. https://doi.org/10.1016/j.techfore. 2012.02 .008

55. Gardiner JM (2002) Episodic memory and autonoetic consciousness: a firstperson approach. In: Baddeley A, Aggleton JP, Conway MA (eds) Episodic memory: new directions in research. Oxford University Press, New York, pp 11-30. https://doi.org/10.1098/rstb.2001.0955

56. Garud R, Dunbar RLM, Bartel CA (2011) Dealing with unusual experiences: a narrative perspective on organizational learning. Organ Sci 22:587-601. https://doi.org/10.1287/orsc.1100.0536

57. Gausemeier J, Fink A, Schlake O (1998) Scenario management: an approach to develop future potentials. Technol Forecast Soc Change 59:111-130. https://doi.org/10.1016/S0040-1625(97)00166-2

58. Gaver WW (1991) Technology affordances. CHI '91 proceedings of the SIGCHI conference on human factors in computing systems, pp 79-84. https://doi.org/10.1145/108844.108856

59. Gavetti G (2012) Toward a behavioral theory of strategy. Organ Sci 23:267285. https://doi.org/10.1287/orsc.1110.0644

60. Gavetti G, Rivkin JW (2007) On the origin of strategy: action and cognition over time. Organ Sci 18:420-439. https://doi.org/10.1287/orsc.1070.0282

61. Gibson JJ (1979) The ecological approach to visual perception. Houghton Mifflin, Boston

62. Gioia DA, Chittipeddi K (1991) Sensemaking and sensegiving in strategic change initiation. Strat Manag J 12:433-448. https://doi.org/10.1002/smj. 4250120604

63. Hambrick DC, Mason PA (1984) Upper echelons: the organization as a reflection of its top managers. Acad Manag Rev 9:193-206. https://doi.org/ $10.2307 / 258434$

64. Hardy C, Palmer I, Phillips N (2000) Discourse as a strategic resource. Hum Relat 53:1227-1248. https://doi.org/10.1177/0018726700539006

65. Hardy C, Thomas R (2014) Strategy, discourse and practice: the intensification of power. J Manag Stud 51:320-348. https://doi.org/10.1111/ joms.12005
66. Haselton MG, Nettle D, Andrews PW (2005) The evolution of cognitive bias. In: Buss DM (ed) The handbook of evolutionary psychology. Wiley, Hoboken, pp 724-746

67. Hideg É (2015) Paradigms in futures field. Corvinus University, Budapest

68. Higgins ET, Cornwell JFM (2016) Securing foundations and advancing frontiers: prevention and promotion effects on judgment \& decision making. Organ Beh Hum Decis Process 136:56-67. https://doi.org/10.1016/j. obhdp.2016.04.005

69. Hiltunen E (2010) Weak signals in organizational futures learning. Helsinki School of Economics, Helsinki

70. Hines A, Bishop P (2006) Thinking about the future: guidelines for strategic foresight. Social Technologies, Washington, DC

71. Hodgkinson GP (1992) Development and validation of the strategic locus of control scale. Strat Manag J 13:311-317. https://doi.org/10.1002/smj. 4250130405

72. Hodgkinson GP, Whittington R, Johnson G, Schwarz M (2006) The role of strategy workshops in strategy development processes: formality, communication, co-ordination and inclusion. Long Range Plan 39:479-496. https://doi.org/10.1016/j.lrp.2006.07.003

73. Hoon C (2007) Committees as strategic practice: the role of strategic conversation in a public administration. Hum Relat 60:921-952. https://doi. org/10.1177/0018726707080081

74. Jarzabkowski P (2004) Strategy as practice: recursiveness, adaptation, and practices-in-use. Organ Stud 25:529-560. https://doi.org/10.1177/ 0170840604040675

75. Jarzabkowski P, Balogun J (2009) The practice and process of delivering integration through strategic planning. J Manag Stud 46:1255-1288. https:// doi.org/10.1111/j.1467-6486.2009.00853.x

76. Jarzabkowski $P$, Burke G, Spee P (2015) Constructing spaces for strategic work: a multimodal perspective. Brit J Manag 26:S26-S47. https://doi.org/10. 1111/1467-8551.12082

77. Jarzabkowski P, Kaplan S (2015) Strategy tools-in-use: a framework for understanding "technologies of rationality" in practice. Strat Manag J 36: 537-558. https://doi.org/10.1002/smj.2270

78. Jarzabkowski P, Kaplan S, Seidl D, Whittington R (2016) On the risk of studying practices in isolation: linking what, who, and how in strategy research. Strateg Organ 14:248-259. https://doi.org/10.1177/ 1476127015604125

79. Jarzabkowski P, Spee AP (2009) Strategy-as-practice: a review and future directions for the field. Int J Manag Rev 11:69-95. https://doi.org/10.1111/j. 1468-2370.2008.00250.x

80. Juslin P, Winman A, Olsson H (2000) Naive empiricism and dogmatism in confidence research: a critical examination of the hard-easy effect. Psychol Rev 107:384-396. https://doi.org/10.1037/0033-295X.107.2.384

81. Kahn H, Wiener AJ (1968) The year 2000 - a framework for speculation on the next thirty-three years. Macmillan, New York

82. Kahneman D, Tversky A (1979) Prospect theory: an analysis of decisions under risk. Econometrica 47:263-291. https://doi.org/10.2307/1914185

83. Kaplan S (2008) Framing contests: strategy making under uncertainty. Organ Sci 19:729-752. https://doi.org/10.1287/orsc.1070.0340

84. Kaplan S, Orlikowski WJ (2013) Temporal work in strategy making. Organ Sci 24:965-995. https://doi.org/10.1287/orsc.1120.0792

85. Kaptelinin V, Nardi B (2012) Affordances in HCl: toward a mediated action perspective. CHI '12 proceedings of the SIGCHI conference on human factors in computing systems, pp 967-976. https://doi.org/10.1145/2207676.2208541

86. Kirkpatrick SA, Locke EA (1996) Direct and indirect effects of three core charismatic leadership components on performance and attitudes. J Appl Psychol 81:36-51. https://doi.org/10.1037/0021-9010.81.1.36

87. Kivetz Y, Tyler TR (2007) Tomorrow I'll be me: the effect of time perspective on the activation of idealistic versus pragmatic selves. Organ Beh Hum Decis Process 102:193-211. https://doi.org/10.1016/j.obhdp.2006.07.002

88. Korte RF, Chermack TJ (2007) Changing organizational culture with scenario planning. Futures 39:645-656. https://doi.org/10.1016/j.futures.2006.11.001

89. Langley A (1989) In search of rationality: the purposes behind the use of formal analysis in organizations. Adm Sci Q 34:598-631. https://doi.org/10. 2307/2393569

90. Laroche H (1995) From decision to action in organizations: decision-making as social representation. Organ Sci 6:62-75. https://doi.org/10.1287/orsc.6.1.62

91. Larsen MV, Willert S (2018) Using management inquiry to co-construct other memories about the future. J Manag Inquiry 27:246-259. https://doi. org/10.1177/1056492617696889 
92. Leonardi PM, Vaast E (2017) Social media and their affordances for organizing: a review and agenda for research. Acad Manag Ann 11:150-188. https://doi.org/10.5465/annals.2015.0144

93. Levin IP, Gaeth GJ, Schreiber J, Lauriola M (2002) A new look at framing effects: distribution of effect sizes, individual differences, and independence of types of effects. Organ Behav Hum Decis Process 88:411-429. https://doi. org/10.1006/obhd.2001.2983

94. Levine SS, Bernard M, Nagel R (2017) Strategic intelligence: the cognitive capability to anticipate competitor behavior. Strat Manag J 38:2390-2423. https://doi.org/10.1002/smj.2738

95. Liu F, Maitlis S (2014) Emotional dynamics and strategizing processes: a study of strategic conversations in top team meetings. J Manag Stud 51: 202-234. https://doi.org/10.1111/j.1467-6486.2012.01087.x

96. Liu W, Aaker J (2007) Do you look to the future or focus on today? The impact of life experience on intertemporal decisions. Organ Behav Hum Decis Process 102:212-225. https://doi.org/10.1016/j.obhdp.2006.02.004

97. Løhre E, Teigen $\mathrm{KH}$ (2017) Probabilities associated with precise and vague forecasts. J Behav Decis Making 30:1014-1026. https://doi.org/10.1002/bdm.2021

98. Maio GR, Olson JM (1995) Relations between values, attitudes, and behavioral intentions. J Exp Soc Psychol 31:266-285. https://doi.org/10.1006/ jesp.1995.1013

99. Mantere S, Vaara E (2008) On the problem of participation in strategy: a critical discursive perspective. Organ Sci 19:341-358. https://doi.org/10.1287/ orsc. 1070.0296

100. March JG (2006) Rationality, foolishness, and adaptive intelligence. Strat Manag J 27:201-214. https://doi.org/10.1002/smj.515

101. McKenna C (2012) Strategy followed structure: management consulting and the creation of a market for 'strategy', 1950-2000. Adv Strateg Manag 29: 153-186

102. McWhorter R, Lynham S (2014) An initial conceptualization of virtual scenario-planning. Adv Dev Hum Resour 16:335-355. https://doi.org/10. $1177 / 1523422314532096$

103. McWorter RR, Lynham SA, Porter DE (2008) Scenario planning as developing leadership capability and capacity. Adv Dev Hum Resour 10:258-284. https://doi.org/10.1177/1523422307313332

104. Meissner P, Brands C, Wulf T (2017) Quantifying blind spots and weak signals in executive judgment: a structured integration of expert judgment into the scenario development process. Int J Forecast 33:244-253. https:// doi.org/10.1016/j.techfore.2012.09.011

105. Meissner P, Wulf T (2013) Cognitive benefits of scenario planning: its impact on biases and decision quality. Technol Forecast Soc Change 80:801-814

106. Mendonça S, Cunha MP, Kaivo-Oja J, Ruff F (2004) Wild cards, weak signals and organizational improvisation. Futures 36:201-218. https://doi.org/10. 1016/S0016-3287(03)00148-4

107. Menon A (2017) Bringing cognition into strategic interactions: strategic mental models and open questions. Strat Manag J 39:168-192. https://doi. org/10.1002/smj.2700

108. Mintzberg H (1987) The strategy concept I: five Ps for strategy, and strategy concept II: another look at why organizations need strategies. Calif Manag Rev 30:11-32. https://doi.org/10.2307/41165263

109. Mueller F, Whittle A, Gilchrist A, Lenney P (2013) Politics and strategy practice: an ethnomethodologically-informed discourse analysis perspective. Bus Hist 55:1168-1199. https://doi.org/10.1080/00076791.2013.838037

110. O'Brien FA, Meadows M (2013) Scenario orientation and use to support strategy development. Technol Forecast Soc Change 80:643-656. https:// doi.org/10.1016/j.techfore.2012.06.006

111. Ocasio W, Joseph J (2005) An attention-based theory of strategy formulation: linking micro-and macroperspectives in strategy processes. Adv Strateg Manag 22:39-36

112. Önkal D, Sayım KZ, Gönül MS (2013) Scenarios as channels of forecast advice. Technol Forecast Soc Change 80:772-788. https://doi.org/10.1016/j. techfore.2012.08.015

113. Orlikowski WJ, Scott SV (2008) Sociomateriality: challenging the separation of technology, work and organization. Acad Manag Ann 2:433-474. https:// doi.org/10.1080/19416520802211644

114. Paliokaitè A, Pačèsa N (2015) The relationship between organisational foresight and organisational ambidexterity. Technol Forecast Soc Change 101:165-181. https://doi.org/10.1016/j.techfore.2014.03.004

115. Peter MK, Jarratt DG (2015) The practice of foresight in long-term planning. Technol Forecast Soc Change 101:49-61. https://doi.org/10.1016/j.techfore. 2013.12.004
116. Pettigrew AM (1977) Strategy formulation as a political process. Int Stud Manag Organ 7:78-87 https://www.jstor.org/stable/41103852

117. Phadnis S, Caplice C, Singh M, Sheffi Y (2014) Axiomatic foundation and a structured process for developing firm-specific intuitive logics scenarios. Technol Forecast Soc Change 88:122-139. https://doi.org/10.1016/j.techfore. 2014.06.019

118. Phelps R, Chan C, Kapsalis SC (2001) Does scenario planning affect performance? Two exploratory studies. J Bus Res 51:223-232. https://doi. org/10.1016/S0148-2963(99)00048-X

119. Pincombe B, Blunden S, Pincombe A, Dexter P (2013) Ascertaining a hierarchy of dimensions from time-poor experts: linking tactical vignettes to strategic scenarios. Technol Forecast Soc Change 80:584-598. https://doi. org/10.1016/j.techfore.2012.05.001

120. Polak F (1973) The image of the future. Elsevier, Amsterdam

121. Poli R (2011) Steps toward an explicit ontology of the future. J Futures Stud 16:67-78

122. Puranam P, Stieglitz N, Osman M, Pillutla MM (2015) Modelling bounded rationality in organizations: progress and prospects. Acad Manag Ann 9: 337-392. https://doi.org/10.5465/19416520.2015.1024498

123. Ramírez R, Churchhouse S, Palermo A, Hoffmann J (2017) Using scenario planning to reshape strategy. MIT Sloan Manag Rev 58:31-37

124. Ramírez R, Österman R, Grönquist D (2013) Scenarios and early warnings as dynamic capabilities to frame managerial attention. Technol Forecast Soc Change 80:825-838. https://doi.org/10.1016/j.techfore.2012.10.029

125. Reitzig M, Sorenson O (2013) Biases in the selection stage of bottom-up strategy formulation. Strat Manag J 34:782-799. https://doi.org/10.1002/smj. 2047

126. Rhisiart M, Miller R, Brooks S (2015) Learning to use the future: developing foresight capabilities through scenario processes. Technol Forecast Soc Change 101:124-133. https://doi.org/10.1016/j.techfore.2014.10.015

127. Rietveld E, Kiverstein J (2014) A rich landscape of affordances. Ecol Psychol 26:325-352. https://doi.org/10.1080/10407413.2014.958035

128. Rohrbeck R, Bade, M (2012) Environmental scanning, futures research, strategic foresight and organizational future orientation: a review, integration, and future research directions. ISPIM Annual Conference 2012 Barcelona, Spain

129. Rohrbeck R, Gemünden HG (2011) Corporate foresight: its three roles in enhancing the innovation capacity of a firm. Technol Forecast Soc Change 78:231-243. https://doi.org/10.1016/j.techfore.2010.06.019

130. Rohrbeck R, Kum ME (2018) Corporate foresight and its impact on firm performance: a longitudinal analysis. Technol Forecast Soc Change 129:105116. https://doi.org/10.1016/j.techfore.2017.12.013

131. Rorty R (1967) Introduction. Metaphilosophical difficulties of linguistic philosophy. In: Rorty R (ed) The linguistic turn. Essays in philosophical method. University of Chicago Press, Chicago, pp 1-40

132. Rotter J (1966) Generalized expectancies for internal versus external control of reinforcement. Psychol Monographs 80:1-28. https://doi.org/10.1037/ h0092976

133. Rouleau L, Balogun J (2011) Middle managers, strategic sensemaking, and discursive competence. J Manag Stud 48:953-983. https://doi.org/10.1111/j. 1467-6486.2010.00941.x

134. Rowland NJ, Spaniol MJ (2017) Social foundation of scenario planning. Technol Forecast Soc Change 124:6-15. https://doi.org/10.1016/j.techfore. 2017.02.013

135. Rozin P, Royzman EB (2001) Negativity bias, negativity dominance, and contagion. Personal Soc Psychol Rev 5:296-320. https://doi.org/10.1207/ S15327957PSPR0504_2

136. Rusting CL (1998) Personality, mood, and cognitive processing of emotional information: three conceptual frameworks. Psychol Bull 124:165-196. https:// doi.org/10.1037/0033-2909.124.2.165

137. Samra-Fredericks D (2004) Managerial elites making rhetorical and linguistic "moves" for a moving (emotional) display. Hum Relat 57:1103-1143. https:// doi.org/10.1177/0018726704047140

138. Schacter DL, Addis DR, Buckner RL (2008) Episodic simulation of future events-concepts, data, and applications. Ann N Y Acad Sci 1124:39-60. https://doi.org/10.1196/annals.1440.001

139. Schoemaker PJH (1995) Scenario planning: a tool for strategic thinking. MIT Sloan Manag Rev 36:25-40

140. Schoemaker PJH, Day GS, Snyder SA (2013) Integrating organizational networks, weak signals, strategic radars and scenario planning. Technol Forecast Soc Change 80:815-824. https://doi.org/10.1016/j.techfore.2012.10.020 
141. Schwartz SH (1992) Universals in the content and structure of values: theoretical advances and empirical tests in 20 countries. Adv Exp Soc Psychol 25:1-65. https://doi.org/10.1016/S0065-2601(08)60281-6

142. Shamir B, House RJ, Arthur MB (1993) The motivational effects of charismatic leadership: a self-concept based theory. Organ Sci 4:577-594 https://doi.org/10.1287/orsc.4.4.577

143. Simon HA (1959) Theories of decision-making in economics and behavioral science. Americ Econ Rev 49:253-283 https://www.jstor.org/stable/1809901

144. Smith GF, Benson PG, Curley SP (1991) Belief, knowledge, and uncertainty: a cognitive perspective on subjective probability. Organ Behav Hum Decis Process 48:291-321. https://doi.org/10.1016/0749-5978(91)90016-M

145. Sonenshein S (2010) We're changing - or are we? Untangling the role of progressive, regressive, and stability narratives during strategic change implementation. Acad Manag J 53:77-512. https://doi.org/10.5465/amj.2010. 51467638

146. Stoffregen $T$ (2002) Affordances as properties of the animal-environment system. Ecol Psychol 15:115-134. https://doi.org/10.1207/ S15326969ECO1502_2

147. Strange JM, Mumford MD (2002) The origins of vision: charismatic versus ideological leadership. Leadersh Q 13:343-377. https://doi.org/10.1016/ S1048-9843(02)00125-X

148. Suddendorf T, Corballis MC (2007) The evolution of foresight: what is mental time travel, and is it unique to humans? Behav Brain Sci 30:299-313. https://doi.org/10.1017/S0140525X07001975

149. Sydow J, Schreyögg G, Koch J (2009) Organizational path dependence: opening the black box. Acad Manag Rev 34:689-709. https://doi.org/10. 5465/amr.34.4.zok689

150. Szpunar KK, McDermott KB (2008) Episodic future thought and its relation to remembering: evidence from ratings of subjective experience. Consciousness Cogn 17:330-334. https://doi.org/10.1016/j. concog.2007.04.006

151. Taleb NN (2007) The black swan: the impact of the highly improbable. Penguin books, London

152. Tiberius V (2011) Grundzüge der Zukunftsforschung. In: Tiberius V (ed) Zukunftsorientierung in der Betriebswirtschaftslehre. Gabler, Wiesbaden, pp 11-87

153. Tiberius V (2011) Hochschuldidaktik der Zukunftsforschung. Wiesbaden, VS

154. Tiberius V (2011) Towards a "planned path emergence" view on future genesis. J Futures Stud 15:9-24

155. Tiberius V, Hirth S (2019) Impacts of digitization on auditing: a delphi study for Germany. J Int Account Audit Taxat, 37:in press. doi:https://doi.org/10. 1016/j.intaccaudtax.2019.100288

156. Tiberius V, Rasche C (2011) Prognosemärkte. J Manag Control 21:467-472. https://doi.org/10.1007/s00187-010-0110-7

157. Turvey M (1992) Affordances and prospective control: an outline of the ontology. Ecol Psychol 4:173-187. https://doi.org/10.1207/ s15326969eco0403_3

158. Tversky A, Kahneman D (1991) Loss aversion in riskless choice: a referencedependent model. Q J Econ 106:1039-1061. https://doi.org/10.2307/ 2937956

159. Vaara E, Whittington $R$ (2012) Strategy-as-practice: taking social practices seriously. Acad Manag Ann 6:285-336. https://doi.org/10.1080/19416520. 2012.672039

160. Van der Merwe L (2008) Scenario-based strategy in practice: a framework. Adv Dev Hum Res 10:216-239. https://doi.org/10.1177/1523422307313321

161. Van Dijk S, Berends H, Jelinek M, Romme AGL, Weggeman M (2011) Microinstitutional affordances and strategies of radical innovation. Organ Stud 32: 1485-1513. https://doi.org/10.1177/0170840611421253

162. Vishnevskiy K, Karasav O, Meissner D (2016) Integrated roadmaps for strategic management and planning. Technol Forecast Soc Change 110: 153-166. https://doi.org/10.1016/j.techfore.2015.10.020

163. Von der Gracht HA, Stillings C (2013) An innovation-focused scenario process - a case from the materials producing industry. Technol Forecast Soc Change 80:599-610. https://doi.org/10.1016/j.techfore.2012.05.009

164. Vroom VH (1964) Work and motivation. Wiley, New York

165. Wallsten TS (1996) An analysis of judgment research analyses. Organ Behav Hum Decis Process 65:220-226. https://doi.org/10.1006/obhd.1996.0022

166. Wallsten TS, Gu HB (2003) Distinguishing choice and subjective probability estimation processes: implications for theories of judgment and for crosscultural comparisons. Organ Behav Hum Decis Process 90:111-123. https:// doi.org/10.1016/S0749-5978(02)00513-7
167. Weick KE (1995) Sensemaking in organizations. Sage, London

168. Whittington R (1996) Strategy as practice. Long Range Plan 29:731-735. https://doi.org/10.1016/0024-6301(96)00068-4

169. Whittington $R$ (2006) Completing the practice turn in strategy research Organ Stud 27:613-634. https://doi.org/10.1177/0170840606064101

170. Wilson TD, Gilbert DT (2003) Affective forecasting. Adv Exp Soc Psychol 35: 345-411. https://doi.org/10.1002/smj.4250110305

171. Wooldridge B, Floyd SW (1990) The strategy process, middle management involvement, and organizational performance. Strat Manag J 11:231-241. https://doi.org/10.1016/j.bushor.2009.04.008

172. Worthington WJ, Collins JD, Hitt MA (2009) Beyond risk mitigation: enhancing corporate innovation with scenario planning. Bus Horizons 52: 441-450. https://doi.org/10.1016/j.bushor.2009.04.008

173. Wright WF, Bower GH (1992) Mood effects on subjective-probability assessment. Organ Behav Hum Decis Process 52:276-291. https://doi.org/10. 1016/0749-5978(92)90039-A

\section{Publisher's Note}

Springer Nature remains neutral with regard to jurisdictional claims in published maps and institutional affiliations.

\section{Submit your manuscript to a SpringerOpen ${ }^{\circ}$ journal and benefit from:}

- Convenient online submission

- Rigorous peer review

- Open access: articles freely available online

- High visibility within the field

- Retaining the copyright to your article

Submit your next manuscript at $\boldsymbol{\nabla}$ springeropen.com 